\title{
Mitigating Biodiversity Concerns in Eucalyptus Plantations Located in South China
}

\author{
Roger A. Williams \\ School of Environment and Natural Resources, Ohio State University, Columbus, Ohio, USA \\ Email: williams.1577@osu.edu
}

Received April 2015

\begin{abstract}
China's growing economy and changes in policies that encourage afforestation, particularly in the industrial sector, have led vast areas in south China to be planted with eucalyptus. These large areas of eucalyptus plantings have elicited environmental concerns for two primary reasons. First there is a concern related to the water demand of eucalyptus, in which it is feared these large areas of eucalyptus will deplete aquifers and create shortages in water supplies. The second concern is in regard to the reduction in biodiversity across large landscapes, leading to further ecological demises. This paper proposes two ideas to possibly mitigate some of the biodiversity concerns. The first is the interplanting of alder-leaf birch (Betula alnoides), a native but dwindling species in south China, to enhance biodiversity and encourage it's reestablishment across the landscape. The second is to encourage retention harvests of alder-leaf birch planted within eucalyptus plantations to enhance not only biological diversity but also structural diversity across the landscape. Alder-leaf birch has demonstrated great potential in producing high quality timber and wood for use in furniture manufacturing.
\end{abstract}

\section{Keywords}

Eucalyptus, Alder-Leaf Birch, Biodiversity, Retention Harvests, Mixed Plantations

\section{Introduction}

China has experienced a rapid increase in the amount of forest plantations created for the purpose of providing a resource base for the expansion of the wood products sector. China's booming economy has created a high demand for construction materials and paper. During the first decade of the 21st century China developed policies that further enhanced the wood products sector, thus encouraging the large expanse of eucalyptus plantations.

The Chinese forest sector has experienced a transformation over the past decade with a marked increase in the demand by China for wood products. This demand has been the result of the growth in exports as well as the increase in domestic demand. Over the same period environmental concerns have resulted in significant constraints being placed on timber production from China's natural forests, while changes in land tenure and use 
rights have paved the way for increased private ownership and investment in plantation forestry.

The Chinese government initiated forestry sector reform beginning in 2000 where a series of policies were introduced that encouraged the development of the forest industry sector. The Chinese government released a Forestry Industry Promotion Plan for the years 2010-2012 with the following four main objectives: 1) to assist the leading 100 key state level forestry enterprises; 2) to support policies that encourage leading enterprises to raise debt finance; 3) to continue and increase the subsidizing the purchase of seedlings required for plantations; and 4) to reduce charges for the forest maintenance fund. Additionally, the Development Plan aim was to maintain the growth rate of forestry's output value at $12 \%$ per year and raise the output value of the forestry industry from RMB1.44 trillion in 2008 to RMB2.26 trillion by 2012.

China has undertaken a set of policy initiatives aimed at expanding its forest cover, most notably the Industrial Base Development Program. This program promotes the establishment of fast-growing and high-yield timber (FGHY) plantations in selected regions by subsidizing plantation establishment with loan interest subsidies, discounted loans from state banks and extended repayment periods [1]. The program's goal is to plant 13.3 million hectares of fast growing plantations between 2001 and 2015, creating an estate that can supply 130 million $\mathrm{m}^{3} \cdot \mathrm{yr}^{-1}$ of timber for China's domestic market. Private companies are expected to play an important role in the operation of the program by leasing or sub-leasing state-owned and collectively owned land for plantation development.

These policy changes have caused a rapid increase in the amount of forest cover, particularly with plantations comprised of fast-growing species. According to the 7th National Forestry Inventory (2004 to 2008), the forest area of China is 195.5 million hectares, $20.4 \%$ of the country's land area. The forest area has increased by 20.5 million hectares since the 6th National Forestry Inventory conducted between 1999 and 2003 [2]. China has the fifth largest forest area of any country in the world with natural forest covering 125 million hectares and plantations totaling 64.5 million hectares [3]. However, China's per capita forest area is only one quarter of the world average, and the percentage of land under forest cover is low by international standards.

The species most commonly used in southern China for FGHY plantations is eucalyptus. The eucalyptus species, endemic to Australia, was a tree that was first introduced into China in 1890 for ornamental purposes, and later developed into large plantations in the 1950's [4]. Since then, it has been used extensively as protection forests and production forests. Much research has been carried out on eucalyptus since the 1980's, which has helped perpetuate its use. As a result, eucalyptus has become a widespread and valuable resource in southern China for commercial timber and provides a variety of oil extracts for medicinal and aromatherapy purposes. The fast growth of eucalyptus also makes this resource readily available for bioenergy use, which is a top priority in China's government agenda as the Renewable Energy Law was implemented beginning in January 2006 [5].

Guangxi, a southern province, has recently realized a sharp increase in the number of eucalyptus plantations due in part to the increased investments by the Chinese government in industrial development and by the forest products companies such as Guangxi Sunway Forest Products, Stora Enso, Sino-Forest Corporation, Guangxi Fenglin Wood Industry Group, Guangxi Huafeng Forestry Inc and Asian Pulp and Paper. Guangxi now is one of the top three provinces accounting for the total area in eucalyptus plantations in China [6].

China now has one of the largest areas of eucalyptus plantations in the world, occupying more than 2.0 million ha of eucalyptus plantations mainly in Guangdong, Guangxi and Hainan provinces [6]. The area of eucalyptus plantations has since increased to 3.13 million hectares in 2010. Fast-growing species and hybrids (e.g., $E$. urophylla, E. tereticornis, E. grandis, E. urophylla $\times$ E. grandis) are most widely planted in South China. These eucalyptus plantations have primarily employed a continuous cropping system, involving clear-cutting, prescribed burning, and mechanical site preparation on the site, and $60 \%-70 \%$ of them have been managed in short rotation for industrial purposes. The normal rotation period of short-rotation eucalyptus plantation is usually 6 or 7 years.

Plantations of eucalyptus and other exotic tree species have been extensively established in southern China during the past 50 years [7]. The total area of eucalyptus plantations in China was around 460,000 ha in 1993 [8], increasing by 100,000 ha or more per year to an estimated 1.3 million ha in 2000 [9] in response to government afforestation programs and cooperative joint ventures between provincial forestry authorities and foreign investors. More recent estimates place the total planted area of eucalyptus in China to more than 2.5 million ha in 2010 [10], making it second only to Brazil, the country with the largest area of eucalyptus plantations with an estimated 3.1 million ha. In addition to their key role in timber and fiber production, eucalypt plantations in 
China have an important ecological role in the re-vegetation of degraded lands [11] [12].

\section{Environmental Concerns}

Investments in the timber and forests by large institutional investors, asset owners and pension funds have increased significantly over the past several years. These investments have the potential to reap handsome returns as investments are made in the biological growth of forests which occurs independently of movements in the financial markets. Forest industries have a similar view of these investments but also look at this investment from the perspective that it is the renewable raw material that provides the basis for the existence of their industry and provides value-added potential to the various products made and sold.

With a heightened awareness of environmental impacts (both negative and positive) of forest management practices, companies must pay more attention to the environmental outcomes of their management activities. Digital and social media have enabled more transparency of company activities than in the past. This includes greater public access to satellite imagery and Google Earth. Greater societal demands and expectations on environmentally responsible practices are becoming more of the norm. Accordingly, there are greater expectations of companies to practice more responsible land stewardship in their management practices. This is becoming more of a requirement of consumers in purchase of various products produced. Subsequently, investors are likewise looking at not only profit margins but the environmental ethics being practiced by said companies.

The introduction of eucalyptus into south China has been controversial. These large areas of eucalyptus plantings have elicited environmental concerns for two primary reasons. First there is a concern related to the water demand of eucalyptus, in which it is feared these large areas of eucalyptus will deplete aquifers and create shortages in water supplies. The second concern is in regard to the reduction in biodiversity across large landscapes, leading to further ecological demises. The fact that eucalyptus is an introduced species to southern China has exacerbated this concern.

Disputes have arisen between larger corporate eucalyptus plantations and the use of land by farmers. The source of these disputes are varied, but tend to focus on issues of land takeover and use by the state, and thereby minimizing farmer's sources of income. There are also concerns over the conversions of large areas of native forests and farmland to eucalyptus plantations, creating less diversity across the landscape and other negative impacts on the environment. Many ecological concerns have been raised regarding the extensive areas planted to eucalyptus, including whether there is adverse effects on floristic composition and species diversity [13]-[16], soil fertility [17], and local hydrology and water use [18] [19]. Large contiguous areas are more susceptible to disease and insects, such as the gall wasp. Many concerns have been raised regarding water usage by eucalyptus trees, a very water-demanding species, upon soil water resources. Many questions in this regard have not been answered, but some literature indicates that this high water usage can be partly mitigated through wider planting spacing [20].

Eucalyptus plantations in several countries have been the subject of criticism because of their high water use and other negative environmental impacts [20]. Examination of the evidence for these claims has usually concluded that well-managed plantations are beneficial rather than detrimental to the environment [21]-[23]. However, some studies indicate that whenever water resources are limited, the area, location and management of plantations must be carefully considered to avoid conflict with other water users [24] [25].

One of the pro-arguments for the vast areas of planted eucalyptus in south China is that it restores a level of biodiversity on lands that have been in agriculture for extensive periods of time. However, one has to be careful about claims that reforestation of any degraded land would offset any loss of species following deforestation [26]. While it is known that the conversion of primary forests to intensive agriculture leads to dramatic losses in biodiversity, there is far less certainty about the conservation to secondary and planted forests [26]-[28]. Biodiversity in eucalyptus plantations has been widely studied since it is one of the major concerns regarding the management of this forest type [13] [16] [29]-[31].

However, depending on forest location and specific management method these studies have found that management of eucalyptus plantations can encourage the regeneration of natural forest biodiversity in the understory and restore degraded land, or it can have an opposite effect by facilitating the recovery of light-demanding grasses and other pioneer weeds, thus suppressing the recruitment of native plants [32]. It is believed that allelopathogenic effects of the eucalyptus litter, which contains a variety of oils and resins from foliage, has an adverse effect on vegetation thus reducing the number and amount of understory species [10] [22]. 
There are a variety of studies that investigate the allelopathic effects of eucalyptus on understory vegetation [33] and results are contrasting. Some studies find, for example, that eucalyptus inhibits understory herbaceous and woody species growth by producing allelochemicals [34] [35]; while on the other hand, some studies find that the overstory eucalypt trees do not seem to inhibit the colonization of understory woody or herbaceous species [29] [33] [36]. A variety of environmental conditions, particularly related to soil depth, texture, and moisture and climate [33] may play a role in this variation of findings.

\section{Mitigating the Concerns}

One possible way to mitigate the biodiversity and other environmental issues/concerns regarding vast areas planted to eucalyptus and still retain high production levels for the growing industries and economy is to develop mixed plantings of eucalyptus with other native fast-growing species. There is much evidence to support the benefits of mixed forest species plantings [37] and the role of mixed forests in maintaining biodiversity and ecosystem function [33] [38] [39]. Many benefits that have been reported with the use of mixed-species plantations include the potential to increase biomass production and carbon sequestration [40]-[45], improve soil fertility and enhance nutrient cycling [41] [46], and protection from pest and disease outbreaks, thus improving risk management [46]-[48]. Even though there often is resistance to utilizing mixed-species plantations for timber production, they show potential to be used as a silvicultural system for growing high value timber and at the same time provide a more diverse range of products [42] [47] [49].

One species that has been receiving much attention lately and is a candidate to consider in mixed plantings with eucalyptus is alder-leaf birch (Betula alnoides Buch.-Ham. ex D. Don) which is indigenous to the northern part of India Peninsula, Myanmar, Indochina Peninsula and south China [50]. This species is fast growing and well formed, and is suitably used to grow large size timber; its wood is commonly used in high-quality furniture making and room decorations [51]. The growth of alder-leaf birch has been shown to be better on shady slopes as compared to sunny slopes [52]. This suggests that alder-leaf birch requires some protection via shady conditions, thus making it potentially suitable to plant in mixtures. Alder-leaf birch also plays important roles in water conservation, long-term maintenance of land fertility and biodiversity of forest ecosystems [50]. It is becoming one of the most important native, broadleaf timber species for plantation establishment in southwestern China [53]-[55]. It is a pioneer species, supporting forest regeneration on marginal lands, clear-cuts, and forest gaps. Because the tree is fast-growing with a straight stem and little tapering, alder-leaf birch is suitable for large-diameter timber cultivation [54]. Alder-leaf birch outperformed other tree species (Mytilaria laosensis, Castanopsis hystrix, Cunninghamia lanceolata, Pinus massoniana) native to south China in terms of height, diameter and total volume growth in plantation situations. Accordingly, alder-leaf birch had the greatest economic gain and potential compared to the other species studied and showed promise as being a valued timber species [56]. The fast growth rate of alder leaf birch allows it to have comparable rotations to eucalyptus, and has wood properties that enable it to become economically competitive with eucalyptus [55].

In a comparative study of alder-leaf birch plantations with native forests, Reference [54] found that 8- to 13-yr-old alder-leaf birch plantations had higher species diversity in the understory compared to the natural native forests. The species richness increased significantly with the increase in plantation age and the understory vegetation changed from pioneer species to more shade-tolerant plants and sciophytes. The fact that alder-leaf birch plantations demonstrated higher diversity than the other native forests indicates that these plantations can facilitate the development of plant species under their canopy in terms of species composition, diversity, and restoring native species diversity. The species could thus not only be a valuable timber species but also be an effective tree species for restoring tree diversity in tropical southwestern China [57]. Alder-leaf birch also shows promise in sequestering carbon in both monocultures and mixed plantings, sequestering 148.42 and 140.33 tC/ha, respectively, at an annual rate of 4.01 and $4.59 \mathrm{t} / \mathrm{ha} / \mathrm{yr}$ [58] which compares to $103.73 \mathrm{tC} / \mathrm{ha}$ reported for mature eucalyptus stands in the Pearl River Delta of south China [59].

Guangxi province is one of the most important areas in China for this species, where the natural populations are fragmented by limestone soil, which is unsuitable for the long-term survival of alder-leaf birch [60] [61]. Within the last two decades, the wide use of this species for furniture and decoration has led to heavy deforestation, consequently resulting in a more fragmented and diminished distribution of this forest type [60]. Therefore, efforts to re-establish this species on the landscape within this province as well as throughout its native range add greater importance in the use of this species in restoration efforts. 


\section{Will It Work?}

The overarching question to this approach is whether mixed plantations of eucalyptus and alder-leaf birch will increase biodiversity, mitigate any soil degradation that may occur from short rotation practices, reduce soil water losses, and be sustainable and economically feasible. While some short term benefits may be sacrificed initially as this system is put into place, the potential long term benefits appear to be promising. Selective thinning of alder-leaf birch has been performed in Yunan province at age 15 years with the resulting value of the lumber produced ranging from RMB $700-1500 \mathrm{~m}^{-3}$ [62]. Alder-leaf birch was final harvested at age 20 years in an agroforestry system with pineapple producing timber at a value ranging from RMB 100,000 - 225,000 ha ${ }^{-1}$, depending on tree size, planting spacing and time of harvest [62].

With eucalyptus continually placed on short rotations, concerns regarding the long term soil sustainability arise. In spite of the fact that many of these forests are fertilized at the time of planting, continuous short rotations expose the soil to rain and greater erosion thereby degrading the soil. This could jeopardize the long term sustainability of these systems. Delayed harvests of alder-leaf birch mixed with eucalyptus would continue to provide protection to soil when eucalyptus is harvested. When it comes time to harvest birch, eucalyptus will be in place to continue to provide soil protection. To the extent biodiversity is enhanced is unknown, but the protection of soil is vital to the development of plant understories in the immediate and long term. Protection of soil plus the presence of alder-leaf birch should facilitate the establishment and growth of a more diverse understory.

Changing social values and expectations have led some of the industries in North America to consider alternatives to clearcut harvesting. The recognition of the short term and long term consequences of this practice has resulted in focusing on what can be done to mitigate some of the negative effects of intensive-fiber oriented management. Subsequently many studies have been conducted to determine both the ecological and economic benefits of retaining forest structure through a method referred to as variable retention harvests (i.e., leaving parts of the forest unharvested) for the purpose of retaining structural diversity, increasing biodiversity and the maintenance of ecosystem functions through retaining legacy systems [63]. Forest industries in North America such as Weyerhaeuser Company, TimbeWest and Interfor have adopted this approach on some of their forest land with success over the past decade. The short answer to offsetting costs associated with such a management approach would be to receive a premium for the products. Society as a whole expects greater care be taken of industrial forests and markets presently exist and more can be created where consumers will pay more for sustainable forest practices. New economic models may need to be created by industries for longer term outlook that develops revenue streams from non-timber sources such as eco-tourism, recreation, carbon, biodiversity and botanicals. While ultimately it will be the marketplace that will determine what non-timber values are worth, the forest industries can play a major role in shaping that discussion through their management practices.

American business magnate and philanthropist John D. Rockefeller said "If you want to succeed you should strike out on new paths, rather than travel the worn paths of accepted success". While the current practices of intensively managing large areas of eucalyptus have been successful in supplying the needed wood resource to the Chinese economy, it is necessary to begin looking toward the next success. China has recently been the world leader in afforestation [3], but concerns have arisen regarding the long-term sustainability of the eucalyptus resource and the intensive practices due to the potential impacts upon the soil [64]-[66]. The forest industries should examine other/additional potentials in the growing "green" economy and become more diversified in their product streams. This could include creating carbon offsets through variable retention harvests. A less tangible but possibly more valuable product is the favorable perception of industries by the societal community.

\section{Acknowledgements}

The author would like to thank Dr. Yuhua Tao, Guangxi Eco-engineering Vocational and Technical College, for her assistance in retrieving some of the Chinese articles for this paper.

\section{References}

[1] Barr, C. and Cossalter, C. (2004) China’s Development of a Plantation-Based Wood Pulp Industry: Government Policies, Financial Incentives, and Investment Trends. Int Forest Rev, 6, 267-281. http://dx.doi.org/10.1505/ifor.6.3.267.59977

[2] FAO (2009) The Importance of China's Forest Products Markets to the unece region. Geneva Timber and Forest Discussion Paper 57. United Nations Economic Commission for Europe. Timber Section, Geneva, Switzerland, 36 p. 
[3] FAO (2010) Global Forest Resources Assessment 2010, Country Report, China. FAO Forestry Department FRA2010/ 042, Rome, $101 \mathrm{p}$.

[4] Jiayu, B. and Siming, G. (1996) Eucalyptus Plantations in China. In: Kashio, M. and White, K., Eds., Reports Submitted to the Regional Expert Consultation on Eucalyptus-Volume II, FAO Regional Office for Asia and the Pacific (RAP), RAP Publication, 1996/44.

[5] RELaw Assist. (2007) Renewable Energy Law in China-Issues Paper. Baker \& McKenzie, the Renewable Energy Generators of Australia (REGA), the Chinese Renewable Energy Industry Association (CREIA) and the Centre for Renewable Energy Development (CRED), 72 p.

[6] Wen, Y.G. (2008) Eucalyptus Ecological, Social Issues and Scientific Development. China Forestry Publishing House, Beijing.

[7] Qi, S.X. (2002) Eucalyptus in China. 2nd Edition, Chinese Forestry Press, Beijing, 517 p.

[8] Bai, J.Y. and Gan, S.M. (1996) Eucalyptus Plantations in China. In: Kashio, M. and White, K., Eds., Reports Submitted to the Regional Expert Consultation on Eucalyptus, October 1993, RAPA Publication 1996/44, FAO Regional Office for Asia and the Pacific, Bangkok, 23-32.

[9] FAO (2001) Global Forest Resources Assessment 2000: Main Report. FAO Forestry Paper 140, United Nations Food and Agriculture Organization, Rome, 511 p.

[10] Zhang, W.J. (2012) Did Eucalyptus Contribute to Environment Degradation? Implications from a Dispute on Causes of Severe Drought in Yunnan and Guizhou, China. Environmental Skeptics and Critics, 1, 34-38.

[11] Corlett, R.T. (1999) Environmental Forestry in Hong Kong: 1871-1977. For Ecol Manag., 16, 93-105.

[12] Zhou, G.Y., Morris, J.D., Yan, J.H., Yu, Z.Y. and Peng, S.L. (2002) Hydrological Impacts of Reafforestation with Eucalypts and Indigenous Species: A Case Study in Southern China. For. Ecol. Manage., 167, 209-222.

Giambastiani, B.M.S. (2007) Evoluzione Idrologica ed Idrogeologica Della Pineta di san Vitale (Ravenna). Ph.D. Thesis, Bologna University, Bologna.

[13] Chen, Q.B. (2001) A Review of Researches on Biodiversity in Eucalyptus Plantations. Chin J Trop Crops, 4, 82-90.

[14] Wen, Y.G., Li, X.X., He, T.P. and Zhong, J.B. (2000) Study on the Functions of Biodiversity Conservation of the Coast Protection Forest in Guangxi Province. Prot For Sci Technol, 1, 1-4.

[15] Wen, Y.G., Liu, S.R. and Chen, F. (2005) The Ecological Problems and Sustainable Management of Industrial Eucalyptus Plantation. J Guangxi Acad Sci, 21, 13-19.

[16] Yu, X.B., Zhong, L.S., Yang, W.D. and Long, T. (1999) Structure of Understory Vegetation in Eucalyptusus Plantations. Chin J Trop Crops, 20, 66-72.

[17] Stape, J.L., Dan, B. and Michael, G.R. (2004) Eucalyptus Production and the Supply, Use and Efficiency of Use of Water, Light and Nitrogen across a Geographic Gradient in Brazil. For Ecol Manag, 193, 17-31. http://dx.doi.org/10.1016/j.foreco.2004.01.020

[18] Calder, I.R., Hall, R.L. and Adlard, P.G., Eds. (1992) Growth and Water Use of Forest Plantations. Wiley, New York.

[19] Patrick, N.J., Lane, J.M., Zhang, N.N., Zhou, G.Y. and Xu, D.P. (2004) Water Balance of Tropical Eucalyptus Plantations in South-Eastern China. Agric For Meteorol, 124, 253-267. http://dx.doi.org/10.1016/j.agrformet.2004.01.015

[20] Morris, J., Zhang, N., Yang, Z., Collopy, J. and Xu, D. (2004) Water Use by Fast-Growing Eucalyptus Urophylla Plantations in Southern China. Tree Physiol., 24, 1035-1044. http://dx.doi.org/10.1093/treephys/24.9.1035

[21] Casson, A. (1997) The Controversy Surrounding Eucalypts in Social Forestry Programs of Asia. Economics Division Working Paper 97/1, National Centre for Development Studies, Australian National University, Canberra, 46 p.

[22] Davidson, J. (1996) Ecological Aspects of Eucalyptus Plantations. In: White, K., Ball, J. and Kashio, M., Eds., Proceedings: Regional Expert Consultation on Eucalyptus. Rapa Publication 1995/6, FAO Regional Office for Asia and the Pacific, Bangkok, 202 p.

[23] Poore, M.E.D. and Fries, C. (1985) The Ecological Effects of Eucalyptus. FAO Forestry Paper No. 59, Food and Agriculture Organization, Rome, 87 p.

[24] Calder, I.R., Hall, R.L. and Adlard, P.G., Eds. (1992) Growth and Water Use of Forest Plantations. Wiley, New York.

[25] Dye, P.J. (1996) Climate, Forest and Streamflow Relationships in South African Afforested Catchments. Comm. For. Rev., 75, 31-38.

[26] Gardner, T.A., Barlow, J., Parry, L.T.W. and Peres, C.A. (2007) Predicting the Uncertain Future of Tropical Forest Species in a Data Vacuum. Biotropica, 39, 25-30. http://dx.doi.org/10.1111/j.1744-7429.2006.00228.x

[27] Dunn, R.R. (2004) Recovery of Faunal Communities during Tropical Forest Regeneration. Conserv Biol., 18, $302-309$. http://dx.doi.org/10.1111/j.1523-1739.2004.00151.x

[28] Wright, S.J. and Muller-Landau, H.C. (2006) The Future of Tropical Forest Species. Biotropica, 38, 207-301. 
[29] Michelsen, A., Lisanework, N., Friis, I. and Holst, N. (1996) Comparisons of Understory Vegetation and Soil Fertility in Plantations and Adjacent Natural Forests in the Ethiopian Highlands. J Appl Ecol, 33, 627-642. http://dx.doi.org/10.2307/2404991

[30] Parrotta, J.A. (1995) Influence of Overstory Composition on Understory Colonization by Native Species in Plantations on a Degraded Tropical Site. J Veg Sci, 6, 627-636. http://dx.doi.org/10.2307/3236433

[31] Yu, X.B. and Li, W.G. (1997) Ecological Problems and Its Review of Research in Eucalyptus Plantations. Chin J Trop Crops, 18, 60-68.

[32] Wen, Y., Duo, Y., Chen, F., Liu, S. and Liang, H. (2010) The Changes of Understory Plant Diversity in Continuous Cropping System of Eucalyptus Plantations. South China. J For Res, 15, 252-258. http://dx.doi.org/10.1007/s10310-010-0179-8

[33] Yirdaw, E. and Luukkanen, O. (2003) Indigenous Woody Species Diversity in Eucalyptus globulus Labill. ssp. Globulus Plantations in the Ethiopian Highlands. Biodiversity and Conservation, 12, 567-582. http://dx.doi.org/10.1023/A:1022483700992

[34] Basanta, M., Vizcaino, E.D., Casal, M. and Morey, M. (1989) Diversity Measurements in Shrubland Communities of Galicia (NW Spain). Vegetatio, 82, 105-112. http://dx.doi.org/10.1007/BF00045024

[35] Madeira, M.A.V., Andreux, F. and Portal, J.M. (1989) Changes in Soil Organic Matter Characteristics Due to Reforestation with Eucalyptus globulus, in Portugal. Sci Total Environ., 81/82, 481-488. http://dx.doi.org/10.1016/0048-9697(89)90157-5

[36] da Silva, J.M.C., Scarano, F.R. and Souza, F.C. (1995) Regeneration of an Atlantic Forest Formation in the Understory of a Eucalyptus grandis Plantation in South-Eastern Brazil. J Trop Ecol., 11, 47-152.

[37] Nichols, J.D., Bristow, M. and Vanclay, J.K. (2006) Mixed-Species Plantations: Prospects and Challenges. For Ecol Manag., 233, 383-390.

[38] Barlow, J., Gardner, T.A., Araujo, I.S., Avila-Pires, T.C., Bonaldo, A.B., Costa, J.E., Esposito, M.C., Ferreira, L.V., Hawes, J., Hernandez, M.I.M., Hoogmoed, M.S., Leite, R.N., Lo-Man-Hung, N.F., Malcolm, J.R., Martins, M.B., Mestre, L.A.M., Miranda-Santos, R., Nunes-Gutjahr, A.L., Overal, W.L., Parry, L., Peters, S.L., Ribeiro-Junior, M.A., da Silva, M.N.F., Silva Motta, C. and Peres, C.A. (2007) Quantifying the Biodiversity Value of Tropical Primary, Secondary, and Plantation Forests. Proceedings of the National Academy of Sciences, 104, 18555-18560. http://dx.doi.org/10.1073/pnas.0703333104

[39] Ren, H., Li, Z.A., Shen, W.J., Yu, Z.Y., Peng, S.L., Liao, C.H., Ding, M.M. and Wu, J.G. (2007) Changes in Biodiversity and Ecosystem Function during the Restoration of a Tropical Forest in South China. Science in China Series C: Life Sciences, 50, 277-284. http://dx.doi.org/10.1007/s11427-007-0028-y

[40] Bauhus, J., van Winden, A.P. and Nicotra, A.B. (2004) Above-Ground Interactions and Productivity in Mixed-Species Plantations of Acacia mearnsii and Eucalyptus globulus. Can. J. For. Res., 34, 686-694. http://dx.doi.org/10.1139/x03-243

[41] Binkley, D. (2003) Seven Decades of Stand Development in Mixed and Pure Stands of Conifers and Nitrogen-Fixing Red Alder. Can. J. For. Res., 33, 2274-2279. http://dx.doi.org/10.1139/x03-158

[42] DeBell, D.S., Whitesell, C.D. and Schubert. T.H. (1985) Mixed Plantations of Eucalyptus and Leguminous Trees Enhance Biomass Production. USDA For. Serv. Res., Paper PSW-175.

[43] Kaye, J.P., Resh, S.C., Kaye, M.W. and Chimmer, R.A. (2000) Nutrient and Carbon Dynamics in a Replacement Series of Eucalyptus and Albizia Trees. Ecology, 81, 3267-3273.

Keenan, R., Lamb, D. and Sexton, G. (1995) Experience with Mixed Species Rainforest Plantations in North Queensland. Commun. For. Rev., 74, 315-321. http://dx.doi.org/10.1890/0012-9658(2000)081[3267:NACDIA]2.0.CO;2

[44] Parrotta, J.A. (1999) Productivity, Nutrient Cycling, and Succession in Single- and Mixed-Species Plantations of Casuarina equisetifolia, Eucalyptus robusta, and Leucaena leucocephala in Puerto Rico. For Ecol Manage., 124, $45-77$.

[45] Resh, S.C., Binkley, D. and Parrotta, J.A. (2002) Greater Soil Carbon Sequestration under Nitrogen-Fixing Trees Compared with Eucalyptus Species. Ecosystems, 5, 217-231. http://dx.doi.org/10.1007/s10021-001-0067-3

[46] Montagnini, F. (2000) Accumulation in Above-Ground Biomass and Soil Storage of Mineral Nutrients in Pure and Mixed Plantations in a Humid Tropical Lowland. For Ecol Manage., 134, 257-270.

[47] Ewel, J.J. (1986) Designing Agricultural Ecosystems for the Humid Tropics. Ann. Rev. Ecol. Syst., 17, $245-271$. http://dx.doi.org/10.1146/annurev.es.17.110186.001333

[48] FAO (1992) Mixed and Pure Forest Plantations in the Tropics and Subtropics. FAO Forestry Paper 103 (Based on the Work of T.J. Wormald). Food and Agriculture Organization of the United Nations, FAO of the UN, Rome.

[49] Montagnini, F., Gonza'les, E. and Porras, C. (1995) Mixed and Pure Forest Plantations in the Humid Neotropics: A Comparison of Early Growth, Pest Damage and Establishment Costs. Commun. For. Rev., 74, 306-314. 
[50] Guo, J.J., Zeng, J., Zhou, S.L. and Zhao, Z.G. (2008) Isolation and Characterization of 19 Microsatellite Markers in a Tropical and Warm Subtropical Birch, Betula alnoides Buch.-Ham. ex. D. Don. Mol Ecol Resour., 8, 895-897. http://dx.doi.org/10.1111/j.1755-0998.2008.02101.x

[51] Zeng, J., Wang, Z., Zhou, S., Bai, J. and Zheng, H. (2003) Allozyme Variation and Population Genetic Structure of Betula alnoides from Guangxi, China. Biochemical Genetics, 41, 66-75. http://dx.doi.org/10.1023/A:1022027832065

[52] Su, F. (2011) Effect of Betula alnoides on the Afforestation of Different Exposures. Journal of Anhui Agricultural Sciences, 18, 10858-10859, 10984. (In Chinese)

[53] Wang, W.B. and Zhang, J.F. (2004) The Manual of Betula alnoides Plantation Establishment Technology. Yunnan Technology Press, Kunming, 6 p.

[54] Wang, W.B., Zhang, J.F., Yang, D.J. and Geng, Y.F. (2011) Comparative Study of Plant Diversity between Betula alnoides Plantations and Adjacent Natural Forests. Taiwan J For Sci, 26, 323-339.

[55] Zeng, J., Zheng, H.S. and Wang, B.G. (1998) Betula alnoides-The Fast-Growing and Valuable Timber Tree Species in Tropical and Southern Sub-Tropical Area. Yunnan For Sci Technol, 98, 18-20. (In Chinese)

[56] Lu, L.H., Cai, D.X., He, R.M. and Guo, W.F. (2006) Evaluation of Tree Species of Plantation in Southwest Guangxi. Forest Research, 2. (In Chinese)

[57] Zhang, J., Yang, D. and Geng, Y. (2012) Plant Diversity among Betula alnoides Plantations and Adjacent Natural Forests. 22-24. In: Heok-Choh, S., Hamid, S.A. and Mei, L., Eds., Asia and the Pacific Workshop-Multinational and Transboundary Conservation of Valuable and Endangered Forest Tree Species, Extended Abstracts from the Workshop held in Guangzhou, China, 5-7 December 2012. IUFRO World Series Vol. 30, 129 p.

[58] Yang, D., Wang, W., Geng, Y. and Qiu, Q. (2008) Comparative Analysis of Ecosystem Carbon Stocks for Pure and Mixed Stands of Betula alnoides. Journal of Fujian College of Forestry, 2, 151-155. (In Chinese)

[59] Hui, Z., Guan, D.S. and Song, M.W. (2012) Biomass and Carbon Storage of Eucalyptus and Acacia Plantations in the Pearl River Delta, South China. Forest Ecol Manag, 277, 90-97. http://dx.doi.org/10.1016/j.foreco.2012.04.016

[60] Zeng, J., Zou, Y., Bai, J. and Zheng, H. (2003) RAPD Analysis of Genetic Variation in Natural Populations of Betula alnoides from Guangxi, China. Euphytica, 134, 33-41.

[61] Zeng, J., Zheng, H.S. and Weng, Q.J. (1999) Geographic Distributions and Ecological Conditions of Betula alnoides Buch.-Ham. ex D.Don in China. Forest Res, 12, 479-484. (In Chinese)

[62] Liang, L., Shen, L., Yang, W., Yang, X. and Zhang, Y. (2009) Building on Traditional Shifting Cultivation for rotational Agroforestry: Experiences from Yunan, China. For Ecol Manage., 257, 1989-1994. http://dx.doi.org/10.1016/j.foreco.2008.11.032

[63] Serrouya, R., and D’Eon, R. (2004) Variable Retention Forest Harvesting: Research Synthesis and Implementation Guidelines. Knowledge Exchange and Technology Extension Program, Sustainable Forest Management Network, 53 p.

[64] Nambiar, E.K.S. (1996) Sustained Productivity of Forests Is a Continuing Challenge to Soil Science. Soil Sci. Soc. Am. J., 60, 1629-1642. http://dx.doi.org/10.2136/sssaj1996.03615995006000060006x

[65] Nambiar, E.K.S. (1999) Pursuit of Sustainable Plantation Forestry. S.Afr. For. J., 189, 45-62.

[66] Powers, R.F., Scott, D.A., Sanchez, F.G., Voldseth, R.A., Page-Dumroese, D., Elioff, J.D. and Stone, D.M. (2005) The North American Long-Term Soil Productivity Experiment: Findings from the First Decade of Research. For Ecol Manag., 220, 31-50. http://dx.doi.org/10.1016/j.foreco.2005.08.003 